\title{
Patterns of the Diversity of Characteristic Species Across Vegetation Ecosystems of Ethiopia
}

\author{
Debissa Lemessa*, Yayehyirad Teka \\ Forest and Range Land Plant Biodiversity Directorate, Ethiopian Biodiversity Institute, Addis Ababa, Ethiopia
}

Email address:

lemdeb@yahoo.com (D. Lemessa)

*Corresponding author

\section{To cite this article:}

Debissa Lemessa, Yayehyirad Teka. Patterns of the Diversity of Characteristic Species across Vegetation Ecosystems of Ethiopia. Ecology and Evolutionary Biology. Vol. 2, No. 3, 2017, pp. 34-44. doi: 10.11648/j.eeb.20170203.11

Received: April 27,2017; Accepted: May 4, 2017; Published: May 27, 2017

\begin{abstract}
Understanding plant species distribution across ecosystems is fundamental for designing conservation mechanisms at different ecological scales. Here, the aim of this study is to examine the pattern of plant species richness, unique/restricted, endemic and threatened species across eleven vegetation ecosystems of Ethiopia. The species data were compiled from the atlas of the potential vegetation of Ethiopia that describes the plant species by ecosystems and elevational gradients. Moreover, the data on threatened species was collated from the Red List Endemic Trees and Shrubs of Ethiopia and Eritrea. The comparative patterns of these different characteristic species were analyzed using descriptive statistics. Moreover, the relationship between the ecosystem characteristic species richness vs. species unique to each ecosystems; ecosystem characteristic species richness vs. species common to ecosystems; ecosystem characteristic species richness vs. species unique to each ecosystems and species unique to each ecosystems vs. endemic species richness across ecosystems was tested with Pearson's correlation using $\mathrm{R}$ statistical program. The results showed that the Acacia-Commiphora woodland bushland ecosystem is comprised of the higher number of species (i.e., 37\% of the total ecosystem characteristic species), while in contrast, the Afroalpine belt and Wooded grassland of the western Gambela region ecosystems had lower species richness (i.e., 1.4-1.5\%) when compared with the other ecosystems. Dry evergreen Afromontane forest and grassland complex ecosystem is composed of the higher number of species that are common to the majority of other ecosystems, but Desert and semi-desert scrubland does not have any species which are common to other ecosystems. The number of ecosystem characteristic species, endemic and threatened species are higher in Acacia-Commiphora woodland bushland ecosystems and the majority are found in Euphorbiaceae and Fabaceae families. Moreover, the ecosystem characteristic species richness in general and of endemic in particular took hump-shaped pattern where the number of species was higher at "mid altitude". These different patterns may indicate that conserving the whole system only at mega scale may not necessarily mean that the rare/unique, endemic and threatened species are conserved. Therefore, the overall results emphasize the importance of understanding the ecological processes in each ecosystem and the corresponding species specific properties to plan and design conservation system following either ecosystem approach or multiple spatial scales.
\end{abstract}

Keywords: Altitudinal Gradient, Endemic Species, Hump-Shaped Pattern, Threatened Species, Vegetation Ecosystems

\section{Introduction}

Understanding the spatial patterns of species distribution is one of the major components in conservation planning mainly under the currently prevailing climate change [1-4]. With this respect, some areas are comprised of enormous diversity, the other extreme areas are devoid of vegetation while most lie in between teemed with intermediate species diversity [5]. Despite there is high diversity of vegetation ecosystems in the tropical regions, the understanding of the spatial pattern and extent of change in species distribution is inadequate [6].

Even though the vegetation is heterogeneously distributed across spatial scales and environmental gradients $[5,4,7,2]$, most of the previous studies undertaken on vegetation ecosystems so far have focused on the diversity of a certain locality or site mainly in understudied tropical regions $[8,9]$. For example, in Ethiopia, many of the earlier studies described vegetation structure only at local scale and lack 
explorations across spatial scales [10-15]. Here, the aim of this study is to fill the existing gap by analyzing the patterns of the diversity of characteristic species, endemic and threatened species across the vegetation ecosystems and elevational gradients of Ethiopia.

The ecosystems in Ethiopia were characterized based on the potential natural vegetation types. These vegetation types are in turn dependent on several factors such as, topographic features (i.e., altitudinal variation and aspect), climate (i.e., precipitation and temperature), geology and soil conditions. The ecosystems in Ethiopia has been described by several authors and previously reported as there are ten (10) ecosystems [16, 18]. However, following similar approach, [17] has recently revised the previous classifications into the following 12 major ecosystem types. (1) Afroalpine belt (AA): is found in areas of highest mountains that peak approximately above an altitude of $3200 \mathrm{~m}$ a. s. 1., (2) Ericaceous belt (EB): is found adjacent to Afroalpine belt ecosystem in most of the higher mountains in Ethiopia between the altitudinal range of $3000-3200 \mathrm{~m}$ a. s. 1., (3) Transitional rain forest ecosystem (TRF): is found adjacent to Moist evergreen Afromontane forest ecosystem in southwest Ethiopia, (4) Moist evergreen Afromontane forest (MAF): is characterized by closed strata that may reach to the height of 30 to $40 \mathrm{~m}$ and where wild coffee is found within the altitudinal range of between $1500-3000 \mathrm{~m}$ a. s. 1 . and in areas receiving an annual rainfall between $700-2000 \mathrm{~mm}$, (5) Dry evergreen Afromontane forest and grassland complex (DAF): this represents the largest and complex ecosystem in Ethiopia and found in different regions of the country between the altitudes of $1800-3000 \mathrm{~m}$, (6) Combretum-Terminalia woodland and wooded grassland (CTW): comprises fairly large sized deciduous trees and grasses and is widely found in lowland areas and western escarpments of Ethiopia, (7) Wooded grassland of the western Gambela region (WGG): is characterized by a tall grass stratum, herbaceous flora, grass species and different acacia species, (8) Acacia-Commiphora woodland bushland (ACB): is found in dry lowland areas of eastern, southern part of Ethiopia and to the east of the highlands in the Rift Valley, (9) Desert and semi-desert scrubland (DSS): here the vegetation cover is scarce and comprises mainly drought tolerant species. Some areas are bare, for example, the salt pans in the Danakil depression lying below $400 \mathrm{~m}$ a. s. 1. altitude in eastern Ethiopia, (10) Riverine vegetation (RV): big rivers and their tributaries form the drainage systems and in areas where altitude is approximately below $1800 \mathrm{~m}$ a. s. 1 . these rivers have riverine forests, (11) Freshwater lakes, lake shores, marsh and floodplain (FLV): the major fresh water lakes include Lake Tana, Lake Ashange, Lake Langano, Lake Ziway, Lake Awasa, Lake Abaya and Chamo and Turkana and (12) Salt lakes, salt-lake shores, marsh and pan vegetation (SLV): is represented by salt tolerant species. The salt lakes in Ethiopia are Lake Asale in Danakil depression of Afar region, Lake Abe, lake Afderera, Lake Abijata and Lake Matahara (Basaka).

\section{Material and Methods}

\subsection{Study Areas}

Ethiopia is located in horn of Africa extending between $3^{\circ}-$ $15^{\circ} \mathrm{N}$ latitudes and $33^{\circ}-48^{\circ} \mathrm{E}$ longitudes. Its area is about 1.13 million square kilometers. Even though Ethiopia is a land locked country, it is called a "Water Tower" for many of the east African countries because of the complex land forms with continuous mountain massifs in eastern and western highlands and the presence of several rivers form watershed between Mediterranean and Indian oceans [19]. The eastern and western highlands are separated by the rift valley that runs from northeast (from Red sea) to southwest through central Ethiopia. The topographic feature of Ethiopia is complexrugged and has wide altitudinal variation of between $125 \mathrm{~m}$ below sea level at Afar depression and peaks to $4533 \mathrm{~m}$ a. s. 1 . at Ras Dashen Mountain. The continued occurrence of the volcanic activity on highlands and throughout the rift valley region has formed different soil types. The soils in Ethiopia are mosaic types, complex in nature and are associated with the different topographic features.

The two main topographic factors that govern the climate of Ethiopia are the proximity to the Equator in the southern border and the complexity of the topography [17]. The variation in topography and altitude has induced the variability in seasons and climatic conditions across Ethiopia. In line with these variations, precipitation also varies, highland and cold areas receive higher precipitation while lowland and desert or hot areas get meager rainfall. The spatial rainfall pattern in the country varies from, unimodal where areas get rainfall during the main rainfall season only once in a year between June-August), bimodal where the areas get main rainfall and also short rainfall during MarchApril and, to some areas where the rainfall occurs throughout the year. These variants have endowed the country to have exclusively diverse ecosystems which comprised of high flora and fauna diversity. Ethiopia is one of the top 25 biodiversity-rich countries in the world [21], and hosts two of the world's 34 biodiversity hotspots, namely, the Eastern Afromontane and the Horn of Africa hotspots. It is also among the countries in the Horn of Africa recognized as the center of diversity and endemism for several plant species. The so far known higher plants in Ethiopia are 6000 species of which $10 \%$ are endemic [22]. However, since the vegetation description is not yet exhaustive in the country, new native and endemic plants are described every time. Among these higher plant species, woody plants constitute about 1000 species [23]. The natural vegetation is classified into 12 major vegetation ecosystems [23, Figure 1]. Forests form the major types of vegetation ecosystems and thus conservation of forest genetic resources is among the priority areas of biodiversity conservation in Ethiopia. About 56.9 million hectares ( $15 \%$ of the area of Ethiopia) is occupied by natural, woodland, grasslands and plantation forests [24, 25]. These forests are depositories and gene pools for high diversity of wild plants such as, coffee and wild relatives of domesticated plants. 


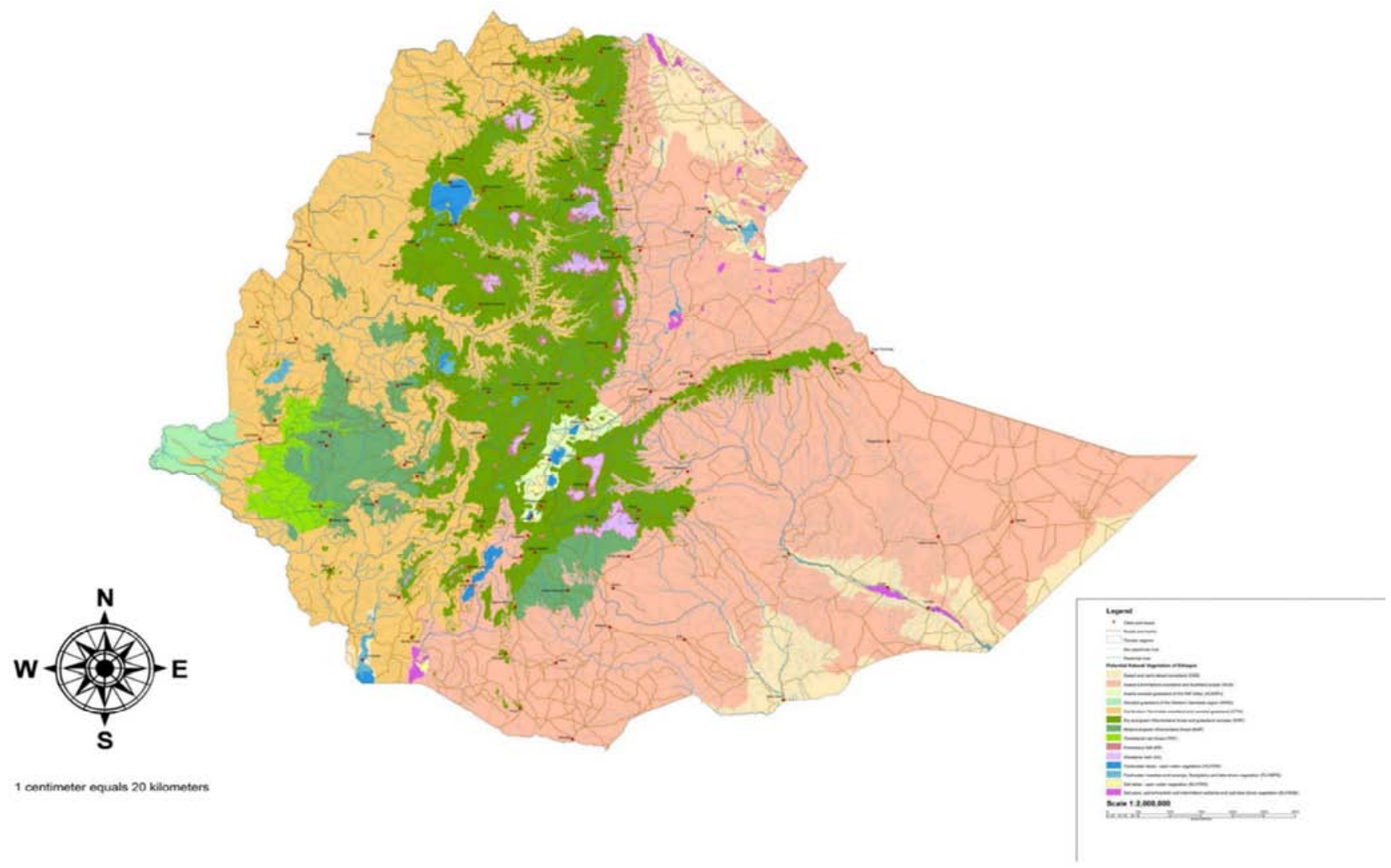

Source: Friis et al. (2010), used with online permission using the link of https://ecodiv.earth/projects/vegetation_ethiopia/).

Figure 1. Map of the potential vegetation ecosystems of Ethiopia.

\subsection{Data Collection}

The twelfth ecosystem, Salt lakes, salt-lake shores, marsh and pan (SLV), was deliberately excluded from this study since the characteristic species are mostly bryophytes and is devoid of vegetation except the presence of few salt tolerant species. Hence, the data of characteristic species of the eleven vegetation ecosystems that were published in Atlas of potential vegetation ecosystems of Ethiopia [17] were collected and compiled for data analysis on the distribution of species by ecosystems and altitudinal gradients. Moreover, the data on IUCN red lists of the endemic plants of Ethiopia were used from the book of The Red List Endemic Trees and Shrubs of Ethiopia and Eritrea [26]. The map produced by [17] for vegetation ecosystems was obtained with online permission using the link of https://ecodiv.earth/projects/vegetation_ethiopia/. Moreover, the information on the forest genetic resources conservation efforts was collated from the unpublished technical reports of Ethiopia biodiversity institute (EBI) of 2016.

\subsection{Statistical Analysis}

We analyzed the comparative pattern of characteristic species across the eleven ecosystems such as species richness, species shared/common to different ecosystems, species specific/ unique to each ecosystems, endemic species across ecosystems using descriptive statistics.
Moreover, the relationship between the ecosystem characteristic species richness vs. species specific/unique to each ecosystems; ecosystem characteristic species richness vs. shared/common species among ecosystems; ecosystem characteristic species richness vs. species/unique specific to each ecosystems and species specific/unique to each ecosystems vs. endemic species richness across ecosystems was tested with Pearson's correlation using R statistical program [version 3.2.5, 27].

\section{Results}

\subsection{General Ecosystem Characteristic Species Richness}

Altogether, about 773 flora species (belong to 124 families) that characterize eleven vegetation ecosystems were compiled from the atlas of potential vegetation of Ethiopia. The ACB ecosystem is comprised of the higher number of species (i.e., $37 \%$ of the total ecosystem characteristic species), while in contrast, the AA and WGG ecosystems had lower species richness (i.e., 1.4-1.5\%) when compared with the other ecosystems (Figure 2A). The DAF and MAF ecosystems share the higher proportion of species $(36 \%, 33 \%$ respectively), FLV shares lower proportion ( $0.88 \%$ ), but DSS does not have any species in common with other ecosystems (Figure 2B). 

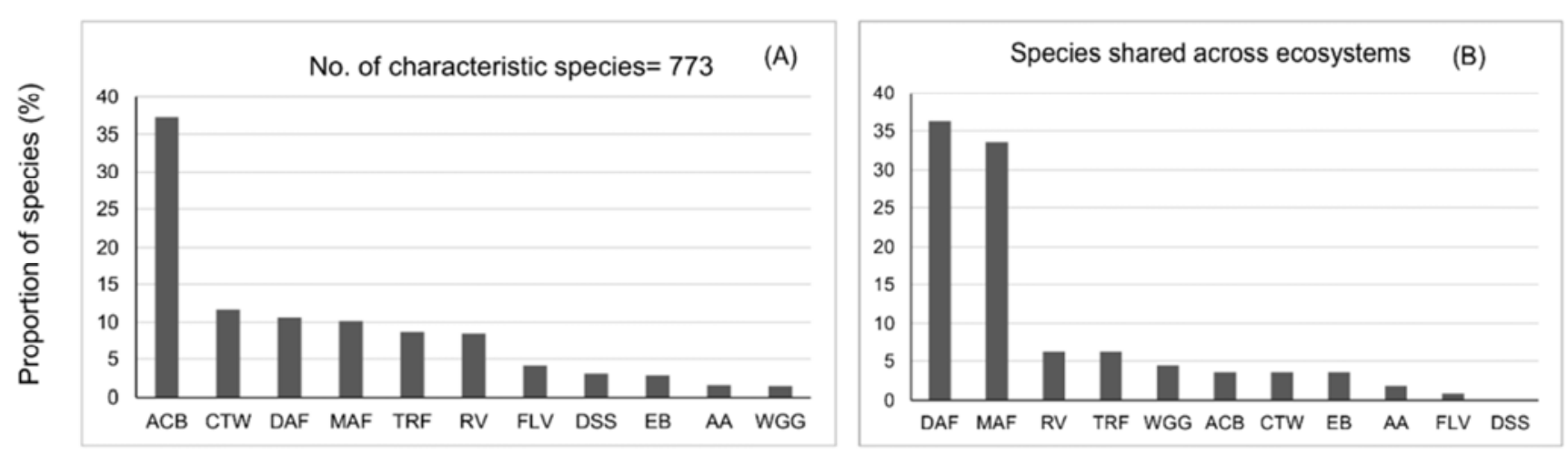

\section{Ecosystems}

Figure 2. The proportion of the ecosystem characteristic species and shared/common species among ecosystems.

The life form that consists of the higher proportion of the total species is tree (38\%), followed by shrub (32.7\%) and herbs (14.9\%), while, the least life forms found are liana and geophytes (i.e., $\leq 0.4 \%$ by proportion, Figure 3 ).

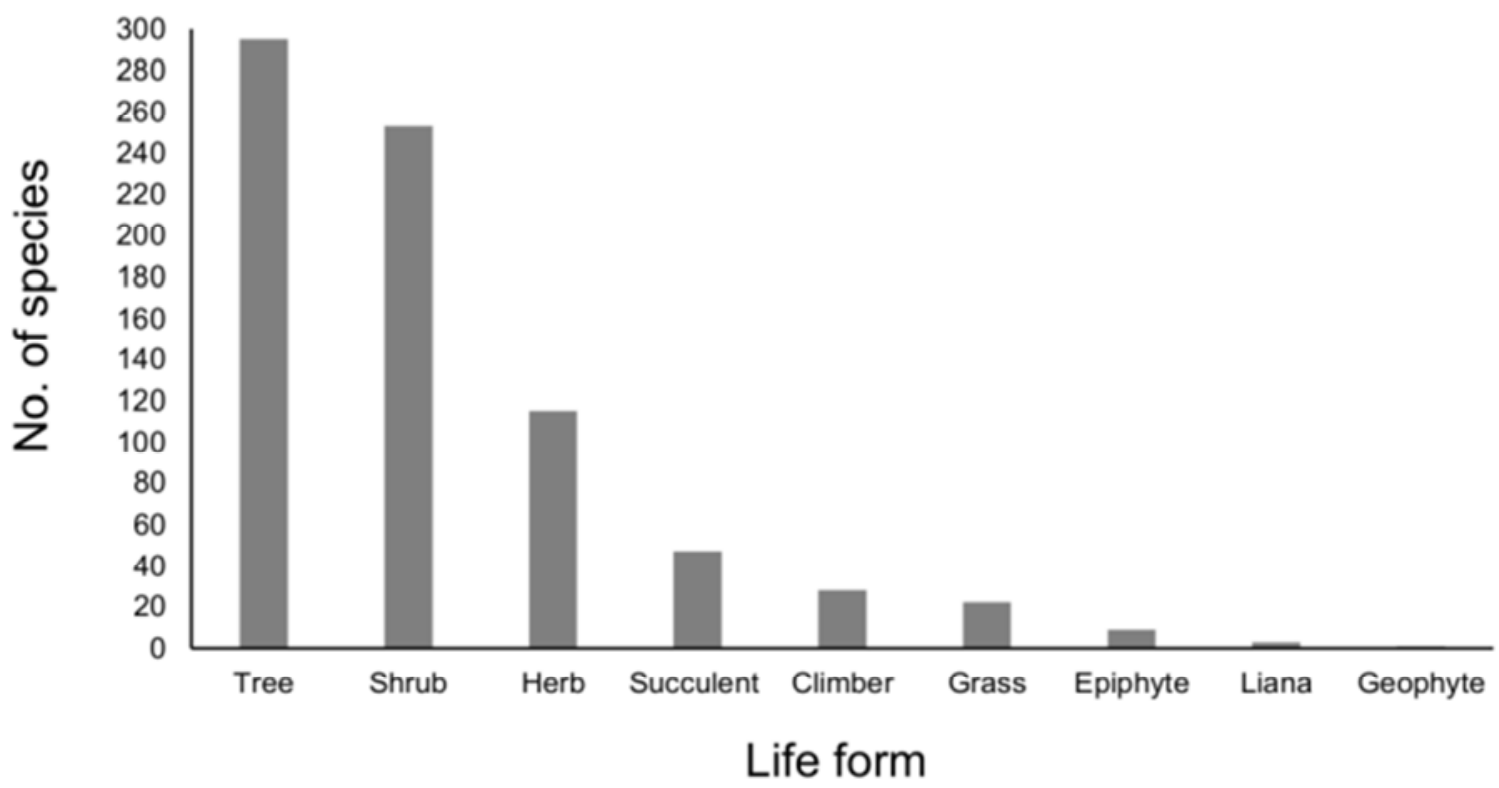

Figure 3. The ecosystem characteristic species richness by life forms.

The richest families in number of species $(n \geq 17)$ in descending order are Euphorbiaceae, Fabaceae, Burseraceae, Acanthaceae and Convolvulaceae (Table 1). And most of these richest families are found in ACB ecosystem.

Table 1. The families that are the richest in species $(n \geq 17)$ in relation to ecosystems and the numbers in parenthesis indicates the number of species in respective families.

\begin{tabular}{|c|c|c|c|c|c|}
\hline \multirow{2}{*}{ Ecosystem } & \multirow[b]{2}{*}{ Acanthaceae } & \multicolumn{2}{|l|}{ Families and list of species } & \multirow[b]{2}{*}{ Euphorbiaceae } & \multirow[b]{2}{*}{ Fabaceae } \\
\hline & & Burseraceae & Convolvulaceae & & \\
\hline \multirow[t]{10}{*}{$\mathrm{ACB}$} & (17) & $(31)$ & (17) & $(42)$ & $(40)$ \\
\hline & Anisotes involucratus & Boswellia microphylla & Astripomoea nogalensis & Bridelia cathartica & Acacia albida \\
\hline & Anisotes tanensis & Boswellia neglecta & Cladostigma hildebrandtioides & Cephalocroton cordofanus & Acacia bussi \\
\hline & Anisotes trisulcus & Commiphora alaticaulis & Cladostigma nigistiae & Croton dichogamus & Acacia condyloclada \\
\hline & Asystasia excellens & Commiphora albiflora & Hildebrandtia africana & Croton meynhartii & Acacia drepanolobuim \\
\hline & Crossandra infundibuliformis & Commiphora ancistrophora & Hildebrandtia aloysii & Croton schimperianus & Acacia etbaica \\
\hline & Ecbolium boranense & Commiphora boiviniana & Hildebrandtia diredawensis & Croton somalense & Acacia etbaica \\
\hline & Ecbolium gymnostachyum & Commiphora boranensis & Hildebrandtia obcordata & Euphorbia adjurana & Acacia goetzei \\
\hline & Ichtyostoma thulinii & Commiphora ciliata & Hildebrandtia puberula & Euphorbia awashensis & Acacia hamulosa \\
\hline & Justicia grisea & Commiphora compestris & Hildebrandtia sepalosa & Euphorbia betulicortex & Acacia hamulosa \\
\hline
\end{tabular}




\begin{tabular}{|c|c|c|c|c|c|}
\hline \multirow{2}{*}{ Ecosystem } & \multicolumn{3}{|c|}{ Families and list of species } & \multirow[b]{2}{*}{ Euphorbiaceae } & \multirow[b]{2}{*}{ Fabaceae } \\
\hline & Acanthaceae & Burseraceae & Convolvulaceae & & \\
\hline & Justicia phillpsiae & Commiphora confusa & Ipomoea chrysosperma & Euphorbia breviarticulata & Acacia nilotica \\
\hline & Justicia potamopila & Commiphora coronillifolia & Ipomoea cicatricosa & Euphorbia burenensis & Acacia ogadensis \\
\hline & Justicia rendlei & Commiphora corrugata & Ipomoea citrina & Euphorbia burgeri & Acacia paolii \\
\hline & Megalochlamys violacea & Commiphora cyclophylla & Ipomoea kituiensis & Euphorbia cryptocaulis & Acacia prasinata \\
\hline & Ruellia discifolia & Commiphora ellenbeckii & Ipomoea marmorata & Euphorbia cryptospinosa & Acacia reficiens \\
\hline & Ruspolia hypocrateriformis & Commiphora gowello & Ipomoea pogonantha & Euphorbia cuneata & Acacia senegal \\
\hline & Satanocrater parudoxus & Commiphora hildebrandtii & Ipomoea somalica & Euphorbia dalettiensis & Acacia seyal \\
\hline & Satanocrater somalensis & Commiphora hodal & Ipomoea spathulata & Euphorbia erlangeri & Acacia tortilis \\
\hline & & Commiphora horrida & & Euphorbia gymnocalycioides & Acacia zizyphispina \\
\hline & & Commiphora mildbraedii & & Euphorbia jatrophoides & Bauhinia ellenbeckii \\
\hline & & Commiphora monoica & & Euphorbia kelleri & Caesalpinia dauensis \\
\hline & & Commiphora myrrha & & Euphorbia longispina & Caesalpinia oligophylla \\
\hline & & Commiphora obovata & & Euphorbia migiurtinorum & Caesalpinia trothae \\
\hline & & Commiphora ogadensis & & Euphorbia monacantha & Cordyla somalensis \\
\hline & & Commiphora quadricincta & & Euphorbia nigrispina & Craibia brevicaudata \\
\hline & & Commiphora rostrata & & Euphorbia nigrispinioides & Dalbergia commiphoroides \\
\hline & & Commiphora serrulata & & Euphorbia omariana & Dalbergia microphylla \\
\hline & & Commiphora sphaerophylla & & Euphorbia piscidermis & Delonix baccal \\
\hline & & Commiphora tenuis & & Euphorbia robecchii & Dichrostachys kirkii \\
\hline & & Commiphora terebinthina & & Euphorbia schefferi & Dicraeopetalum stipulare \\
\hline & & Commiphora truncata & & Euphorbia sebsebei & Entada leptostachya \\
\hline & & Commiphora tubuk & & Euphorbia somalensis & Erythrina burana \\
\hline & & & & Euphorbia tescorum & Erythrina melanacantha \\
\hline & & & & Euphorbia uniglans & Indigofera binderi \\
\hline & & & & Flueggea leucopyrus & Indigofera curvirostrata \\
\hline & & & & Givotia gosai & Indigofera lupatana \\
\hline & & & & Jatropha dichtar & Indigofera macrantha \\
\hline & & & & Jatropha ellenbeckii & Ormocarpum muricatum \\
\hline & & & & Jatropha quercifolia & $\begin{array}{l}\text { Ormocarpum } \\
\text { trachycarpum }\end{array}$ \\
\hline & & & & Jatropha rivae & Platycelyphium voense \\
\hline & & & & Phyllanthus borenensis & Senna baccarinii \\
\hline & & & & Phyllanthus hildebrandtii & \\
\hline \multirow[t]{19}{*}{ CTW } & & & & & (18) \\
\hline & & & & & Abrus precatorius \\
\hline & & & & & Acacia amythetophylla \\
\hline & & & & & Acacia gerrardii \\
\hline & & & & & Acacia hecatophylla \\
\hline & & & & & Acacia hockii \\
\hline & & & & & Dalbergia melanoxylon \\
\hline & & & & & Dichrostachys cinerea \\
\hline & & & & & Entada africana \\
\hline & & & & & Entada venenifica \\
\hline & & & & & Indigofera garckeana \\
\hline & & & & & Lonchocarpus laxiflorus \\
\hline & & & & & Mucuna stans \\
\hline & & & & & Ormocarpum pubescens \\
\hline & & & & & Piliostigma thonningii \\
\hline & & & & & Pterocarpus lucens \\
\hline & & & & & Senna singueana \\
\hline & & & & & Tamarindus indica \\
\hline & & & & & Taverniera schimperi \\
\hline
\end{tabular}




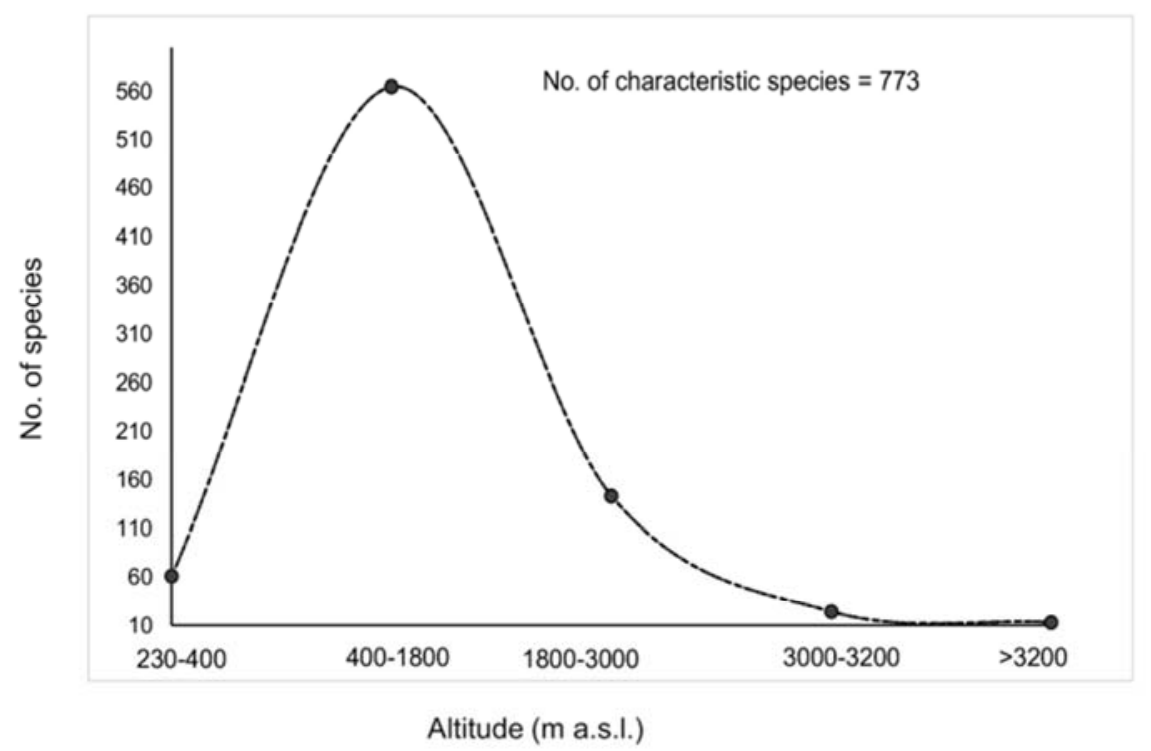

Figure 4. The hump-shaped pattern of the richness of the ecosystem characteristic species in relation to altitudinal gradient.

\subsection{Specific/Unique Species to Each Ecosystem}

The species specific/unique to an ecosystem was higher in ACB ecosystem (42\%) while it was lower in WGG $(0.96 \%)$ when compared with the total number of species specific to each ecosystem (Figure 5). The number of species specific to each ecosystems was strongly and positively correlated with the ecosystems characteristic species richness $(r=0.99)$ where the proportion of species which are specific to each ecosystem increased with increasing the proportion of species richness across ecosystems $\left(\mathrm{R}^{2}=0.97, \mathrm{P}<0.001\right.$, Figure 6A).

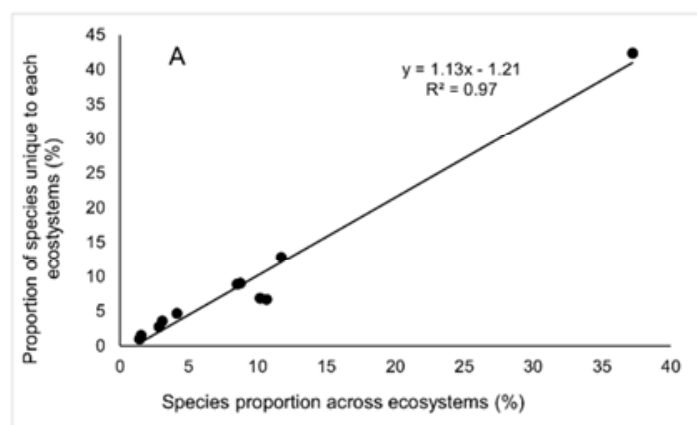

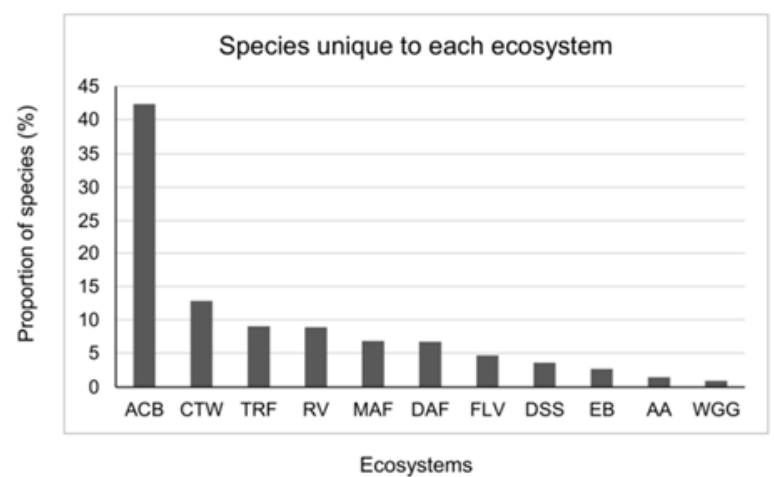

Figure 5. The proportion of unique/specific species richness across ecosystems.
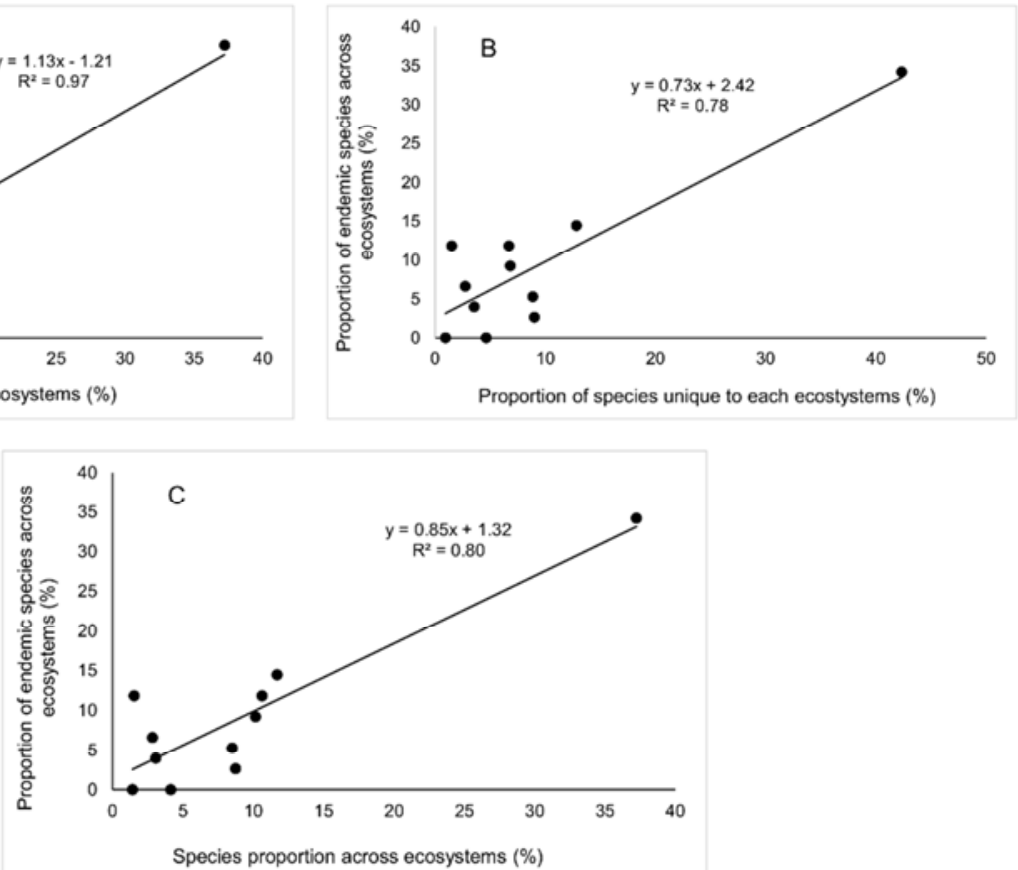

Figure 6. The Pearson's correlation between the proportion of ecosystem characteristic species richness vs. unique species, unique species vs. endemic species, and ecosystem characteristic species vs. endemic species. 


\subsection{Endemic Species Across Ecosystems}

The number of endemic species was higher in ACB (34\%), but no endemic species was recorded in FLV and WGG ecosystems (Figure 7). The proportion of endemic species across ecosystems and the proportion of species which are specific to each ecosystem also had a strong positive correlation $(\mathrm{r}=0.88)$; the proportion of endemic species increased with increasing proportion of species which are specific to each ecosystems $\left(R^{2}=0.78, P<0.001\right.$, Figure $\left.6 B\right)$. Moreover, the proportion of endemic species was strongly and positively correlated with the proportion of the ecosystem characteristic species richness $(r=0.89)$ and here the proportion of endemic species was increasing as the proportion of the ecosystem characteristic species richness increases $\left(\mathrm{R}^{2}=0.80, \mathrm{P}<0.001\right.$, Figure $\left.6 \mathrm{C}\right)$.

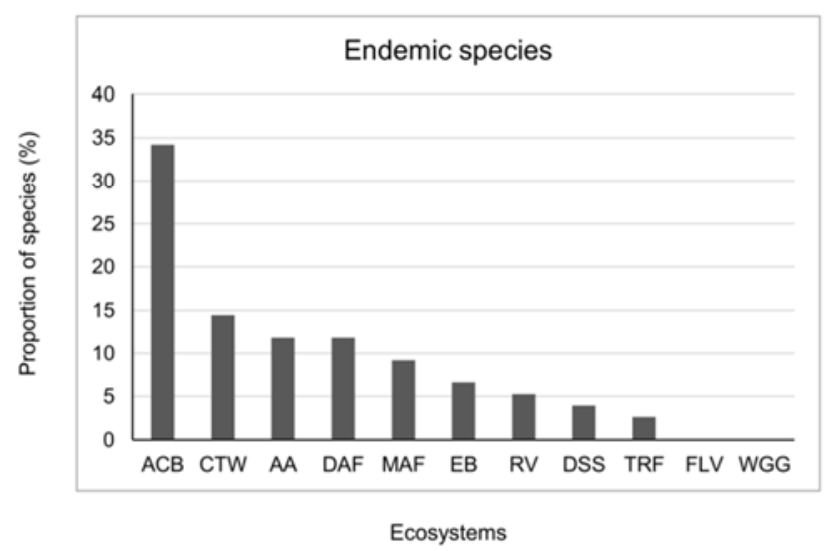

Figure 7. The proportion of endemic species richness across ecosystems.

The pattern of endemic plants species richness across altitudinal gradient was found to be higher at approximately mid altitude and then decreases with increasing altitude to $3200 \mathrm{~m}$ and again showed increasing trend beyond the altitude of $3200 \mathrm{~m}$ (Figure 8 ).

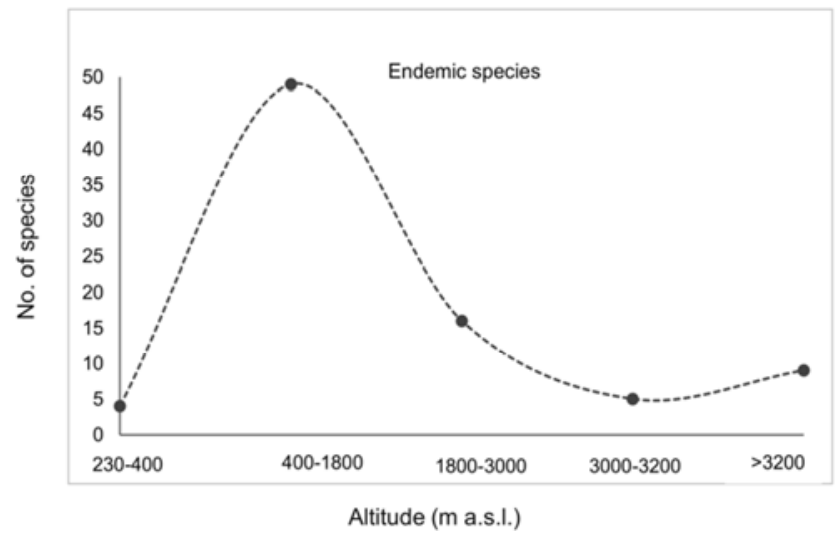

Figure 8. The pattern of the endemic species richness in relation to altitudinal gradient.

\subsection{Threatened Species Across Ecosystems}

The ACB ecosystem comprises the higher number of the plant species that were characterized under the different IUCN red list categories. For example, the number of species that are under critically endangered, endangered and vulnerable are higher in ACB when compared with other ecosystems (Figure 9). In RV and TRF ecosystems, no plant species was characterized under critically endangered and near threatened (Figure 9). The higher number of species that were threatened are found in the families of Fabaceae and Euphorbiaceae in DAF and ACB ecosystems (Table 2). Although the conservation efforts are so meager when compared with the diversity of ecosystems in the country and the number of in-situ conservation sites established is higher in DAF but relatively lower in ACB ecosystem (Figure 10).

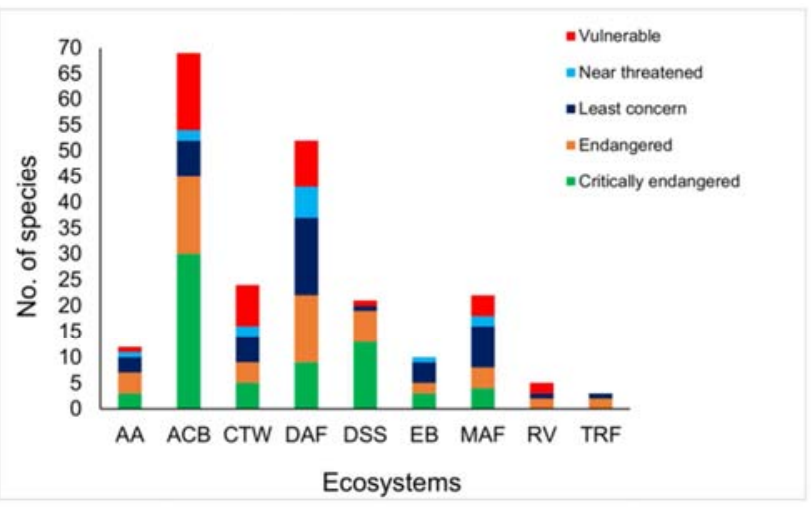

Figure 9. The pattern of the number of species in relation to the IUCN threatened category across ecosystems.

In total, until 2016, in-situ conservation sites were established by EBI only in five ecosystems out of the twelve in the country (Figure 10).

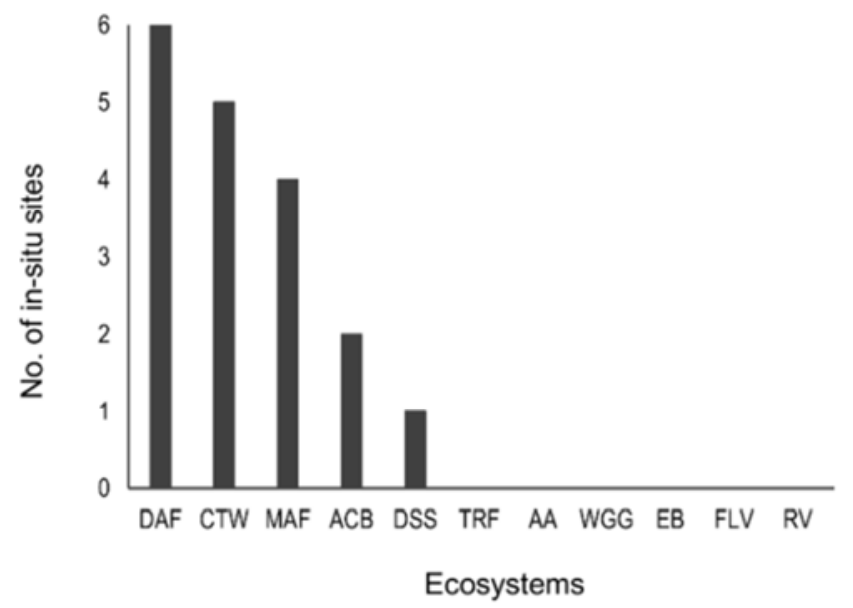

Figure 10. The number of in-situ sites established until 2016 by ecosystems. 


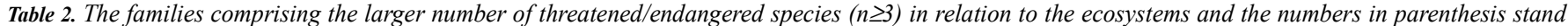
for the number of species in respective families.

\begin{tabular}{|c|c|c|c|}
\hline \multirow{2}{*}{ Ecosystems } & \multicolumn{3}{|l|}{ Families and list of species } \\
\hline & Asteraceae & Euphorbiaceae & Fabaceae \\
\hline \multirow[t]{5}{*}{ AA } & & & (4) \\
\hline & & & Euryops pinifolius \\
\hline & & & Helichrysum horridum \\
\hline & & & Crotalaria exaltata \\
\hline & & & Indigofera ellenbeckii \\
\hline \multirow[t]{4}{*}{ EB } & & & (3) \\
\hline & & & Crotalaria agatiflora \\
\hline & & & Crotalaria exaltata \\
\hline & & & Indigofera ellenbeckii \\
\hline \multirow[t]{5}{*}{ MAF } & (4) & & (3) \\
\hline & Echinops ellenbeckii & & Crotalaria intonsa \\
\hline & Helichrysum elephantinum & & Crotalaria sacculata \\
\hline & Stomatanthes meyeri & & Sesbania melanocaulis \\
\hline & Vernonia tewoldei & & \\
\hline \multirow{16}{*}{ DAF } & Maytenus addat & & Acacia bavazzanoi \\
\hline & Maytenus harenensis & & Stomatanthes meyeri \\
\hline & Maytenus parviflora & & Acacia negrii \\
\hline & Maytenus serrata & & Acacia venosa \\
\hline & & & Argyrolobium schimperianum \\
\hline & & & Crotalaria agatiflora \\
\hline & & & Crotalaria exaltata \\
\hline & & & Crotalaria intonsa \\
\hline & & & Crotalaria rosenii \\
\hline & & & Indigofera ellenbeckii \\
\hline & & & Indigofera rothii \\
\hline & & & Kotschya recurvifolia \\
\hline & & & Taverniera abyssinica \\
\hline & & & Taverniera schimperi \\
\hline & & & Tephrosia dichroocarpa \\
\hline & & & Vigna debanensis \\
\hline \multirow[t]{15}{*}{ ACB } & (7) & (14) & (11) \\
\hline & Blepharispermum obovatum & Euphorbia baleensis & Acacia bricchettiana \\
\hline & Kleinia gypsophila & Euphorbia betulicortex & Acacia prasinata \\
\hline & Kleinia negrii & Euphorbia burgeri & Acacia pseudonigrescens \\
\hline & Phagnalon quartinianum & Euphorbia dalettiensis & Crotalaria sacculata \\
\hline & Pseudoblepharispermum bremeri & Euphorbia doloensis & Erythrina burana \\
\hline & Vernonia dalettiensis & Euphorbia ellenbeckii & Indigofera kelleri \\
\hline & Vernonia tewoldei & Euphorbia nigrispinioides & Kotschya recurvifolia \\
\hline & & Euphorbia ogadenensis & Rhynchosia erlangeri \\
\hline & & Euphorbia somalensis & Rhynchosia erythraea \\
\hline & & Euphorbia tetracantha & Taverniera abyssinica \\
\hline & & Euphorbia uniglans & Taverniera schimperi \\
\hline & & Phyllanthus borenensis & \\
\hline & & Tragia abortiva & \\
\hline & & Tragia negeliensis & \\
\hline \multirow[t]{5}{*}{ CTW } & (3) & (4) & \\
\hline & Bothriocline schimperi & Acalypha marissima & \\
\hline & Vernonia cylindrica & Phyllanthus dewildiorum & \\
\hline & Vrnonia thulinii & Phyllanthus limmuensis & \\
\hline & & Tragia abortiva & \\
\hline \multirow[t]{8}{*}{ DSS } & & (7) & (5) \\
\hline & & Erythrococca uniflora & Acacia bricchettiana \\
\hline & & Euphorbia doloensis & Acacia prasinata \\
\hline & & Euphorbia ellenbeckii & Acacia pseudonigrescens \\
\hline & & Euphorbia fissispina & Indigofera curvirostrata \\
\hline & & Euphorbia ogadenensis & Indigofera kelleri \\
\hline & & Monadenium shebeliensis & \\
\hline & & Phyllanthus borenensis & \\
\hline
\end{tabular}




\section{Discussions}

The ecosystem characteristic species richness and distribution is dissimilar across vegetation ecosystems (Figure 2). The contribution of trees, shrubs and herbs to the ecosystem characteristic species richness is higher when compared with other plant life forms such as, succulents, grasses, climber, liana, epiphytes and geophytes (Figure 3).

The endemic species richness is higher across ecosystems where there is higher richness in characteristic species and higher richness of species specific or unique to each ecosystem (Figure 2, 5 \& 7). However, no such pattern was found where there is higher number of species that are shared or common to other ecosystems. For example, when compared with other ecosystems, DAF and MAF ecosystems had higher species richness that are common/shared, but they comprised of lower number of species that are endemic and unique to each ecosystem (Figure 2B, 5 \& 7). DSS ecosystem had lower species richness and also does not share any species with other ecosystems. Although DSS, FLV and WGG ecosystems are similar by having lower characteristic species richness and unique species, FLV and WGG do not have endemic plant species (Figure 2A, 5 \& 7). Surprisingly, the endemic species richness was found to be higher in AA ecosystem despite the ecosystem characteristic species richness, unique species and the shared species are lower when compared with most of the other ecosystems (Figure 7). Such pattern may be related to the effect of altitudinal gradient since AA ecosystem mainly covers the higher altitudes where the number of endemic species leveled off between $3000-3200 \mathrm{~m}$ but increased starting from the elevation of $3200 \mathrm{~m}$ (Figure 7). However, still the highest richness in characteristic and endemic species was found between the altitudes of 400-1800m (Figure $4 \& 8$ ). This result is in congruent with the previous studies that denoted that the endemism shows inconsistent pattern with the variation along altitudinal gradient despite the general pattern in the tropics is hump-shaped and the endemic plant species richness reaches maxima at mid altitudes-the range of mid altitude varies among studies from different regions [28, 29]. These results indicate that altitude could be one of the factors determining plant distribution and species composition in tropical region $[30,31]$. In this connection, the ecosystems vary in several environmental variables mainly in altitude, edaphic and the corresponding precipitation, temperature and other topographic features such as slope and aspects where the cumulative effect of which may either directly or indirectly influence the spatial distribution of plants. Moreover, the variation in species specific characteristic such as, dispersal range, spatial population structure, adaptive variation and competitive ability in interaction with the historical ecological processes, climatic filters and anthropogenic effects may influence the general distribution of plants and endemism [28, 32]. The species which are found common to different ecosystems are the ones which have wider adaptive ability and hence may also better adapt to the currently prevailing climate change when compared with those species which are restricted to each specific ecosystem.

In part, the impact of spatial population structure and disturbance on plant distribution can be evidenced by the pattern that though ACB ecosystem had higher proportion of characteristic species, unique and endemic species, it at the same time also is comprised of higher proportion of species that were critically endangered, endangered and vulnerable (Figure 2A \& 9). Of course, the dissimilarity in species diversity not only occurs among ecosystems, but also can be observed spatially within an ecosystem due to the variation in biotic interactions and species specific dispersal ability [3336]. Moreover, the variation in edaphic and microclimatic factors across spatial scales, altitude gradients and in topographic aspects differently affect the species adaptability, species composition and distribution structure as also found by the previous findings from China and South Africa [37, 6, 38]. This variation could be related to the impact of different habitat conditions such as, moisture availability, formed by different topographic features on spatial plant distribution.

The proportion of the plants species that were characterized under different IUCN red lists apparently vary across ecosystems (Figure 9) which could be due to the differences in anthropogenic impacts and changes in climatic conditions. For instance, from all vegetation ecosystems present in Ethiopia, DAF is the most disturbed and exploited ecosystem [17] and as a result, next to ACB, DAF has higher proportion of species that were described under IUCN red list categories (Figure 9). Moreover, the families such as, Euphorbiaceae and Fabaceae are the most rich in number of species and at the same time are comprised of the higher number of endangered species in DAF and ACB ecosystems. Presumably, this variation in level of disturbance might have mediated the conservation efforts on forest genetic resources to be relatively skewed to these ecosystems (Figure 10). These results emphasize that the conservation system that targets each specific species is vital since conserving only the whole ecosystems at mega scale may not be adequate to conserve the rare/threatened species in the system [39, 40]. This notion could also work for other mobile organisms such as, bird and insect pollinator communities in which the conservation of ecosystem as a system would also consider the rare/threatened species [41]. In general, the present study indicates the importance of exploring the species composition in relation to the spatial and environmental gradients with respective to the prevailing ecological processes specific to each ecosystem to identify the appropriate conservation approach and correspondingly set conservation priority that fits to each characteristic species across ecosystems.

\section{Conclusion}

The present study accentuates that the plant species richness, distribution, uniqueness, endemism and threatened 
species exhibit dissimilarity among ecosystems and altitudinal gradients. Here, some species are restricted or specific to a particular ecosystem while others, on the contrary, share/are common to different ecosystems that differ in ecological variables. Elevational pattern of the ecosystem characteristic species richness also showed a hump-shaped pattern. The cumulative effect of environmental variation (e.g. altitude, edaphic and climatic filters: precipitation and temperature, slope and topographic aspects), the anthropogenic effects and the variation in species specific properties (i.e., dispersal range, spatial population structure, adaptive and competitive ability) may differently influence the spatial distribution of plants, endemism and whether threatened or not across ecosystems. However, the species which are common to different ecosystems could have wider adaptability and better withstand the currently prevailing climate change when compared with those species which are restricted to each specific ecosystem. These different patterns may indicate that conserving the whole system only at mega scale may not necessarily mean that the rare/unique and threatened species are conserved. Therefore, the overall results emphasize the importance of understanding the ecological processes in each specific ecosystem and the corresponding species specific properties to plan and design conservation system following either ecosystem approach or multiple spatial scales.

\section{References}

[1] Mereta, S. T., Boets, P. \& Bayih, A. A. et al. 2012. Analysis of environmental factors determining the abundance and diversity of macroinvertebrate taxa in natural wetlands of Southwest Ethiopia. Ecological Informatics. 7: 52-61.

[2] Kouba, Y., Martínez-García, F., de Frutos, Á. \& Alados, C. L. 2014. Plant $\beta$-diversity in human-altered forest ecosystems: the importance of the structural, spatial, and topographical characteristics of stands in patterning plant species assemblages. European Journal of Forest Research. 133: 1057-1072.

[3] Hylander, K. 2006. Riparian zones increase regional species richness by harboring different, not more, species : comment. Ecology. 87: 2126-2128.

[4] Baselga, A. 2010. Partitioning the turnover and nestedness components of beta diversity. Global Ecology and Biogeography. 19: 134-143.

[5] Gaston, K. J. 2000. Global patterns in biodiversity. Nature 405: 220-227.

[6] Scholtz, R. S., Iker, G. A. K. \& Mit, I. P. J. S. 2014. Identifying drivers that influence the spatial distribution of woody vegetation in Kruger National Park, South Africa. Ecosphere. 5: 71 http://dx.doi.org/10.1890/ ES14-00034.1.

[7] Baselga, A. 2012. The relationship between species replacement, dissimilarity derived from nestedness, and nestedness. Global Ecology and Biogeography. 21: 12231232 .
[8] Senbeta, F., Schmitt, C., Woldemariam, T., Boehmer, H. J., \& Denich, M. 2014. Plant Diversity, Vegetation Structure and Relationship between Plant Communities and Environmental Variables in the Afromontane Forests of Ethiopia. SINET: Ethiopian Journal of Science 37: 113-130.

[9] Socolar JB, Gilroy JJ, Kunin WE. \& Edwards, D. P. 2015. How should beta-diversity inform biodiversity conservation? Trends in Ecology and Evolution 31: 67-80.

[10] Soromessa, T., Teketay, D. \& Demissew, S. 2004. Ecological study of the vegetation in Gamo Gofa Zone, southern Ethiopia. Journal of Tropical Ecology. 45: 209-221.

[11] Senbeta, F. \& Teketay, D. 2002. Soil seedbank in plantations and adjacent natural dry Afromontane rainforests of central and southern Ethiopia. Journal of Tropical Ecology. 43: 229242.

[12] Yineger, H., Kelbessa, E., Bekele, T. \& Lulekal, E. 2008. Floristic composition and structure of the dry afromontane forest at bale mountains national park, Ethiopia. SINET: Ethiop Journal of Science. 31: 103-120.

[13] Didita, M., Nemomissa, S. \& Woldemariam, T. 2010. Floristic and structural analysis of the woodland vegetation around. Journal of Forestry Research. 21:395-408.

[14] Zegeye, H., Teketay, D. \& Kelbessa, E. 2011. Diversity and regeneration status of woody species in Tara Gedam and Abebaye forests, northwestern Ethiopia. Journal of Forestry Research. 22: 315-328.

[15] Dalle, G. 2015. Floristic composition, population structure and conservation status of woody species in Shashemene-Munessa natural forest, Ethiopia. Ethiopian Journal of Biodiversity. 1: 21-44.

[16] Friis, I. 1992. Forests, and forest trees of northeast tropical Africa. Their natural habitats and distribution patterns in Ethiopia, Djibouti and Somalia. Royal Botanic Gardens, Kew. Additional Series XV. HMSO, London.

[17] Friis, I., Demissew, S. \& van Breugel, P. 2010. Atlas of the Potential Trees/shrubs of Ethiopia. Det Kongelige Danske Videnskabernes Selska, Specialtrykkeriet Viborg a-s, Copenhagen, Denmark.

[18] IBC. 2009. Ethiopia's 4th Country Report to Convention on Biological Diversity (CBD), November 2009, Addis Ababa, Ethiopia.

[19] Wondefrash, M. 2003. Wetlands, birds and important bird areas in Ethiopia. In: Proceedings of a seminar on the resources and status of Ethiopia's wetlands, IUCN, PP. 25-36.

[20] Last, G. 2009. The geology and soils of Ethiopia and Eritrea. PP. 25-26. In: Ash, J \&. Atkins, J. Birds of Ethiopia and Eritrea- an atlas of distribution. Christopher Helm, London.

[21] WCMC.1994. Biodiversity Data Sourcebook. World Conservation Monitoring Centre, World Conservation Press, Cambridge, UK.

[22] Hedberg, I., Friis, I. \& Person, E. 2009. General Part and Index to Vol. 1-7. Flora of Ethiopia and Eritrea Volume 8. The National Herbarium, Addis Ababa, Ethiopia and Uppsala, Sweden.

[23] IBC. 2012. The Sate of Forest Genetic Resource of Ethiopia. Country Report Submitted to FAO, Addis Ababa, Ethiopia. 
[24] Bekele, M. 2011. Forest plantations and woodlots in Ethiopia: African Forest Forum, Nairobi, GPO Kenya.

[25] FRA. 2010. Global Forest Resources Assessment: Country Report, Ethiopia. FAO, Rome, Italy.

[26] Vivero J. L., Kelbessa, E. \& Demissew, S. 2005. The Red List of Endemic trees and shrubs of Ethiopia and Eritrea. Fauna and Flora International, Cambridge printers, United Kingdom.

[27] R Development Core Team. 2016. R: A language and environment for Statistical computing. R Foundation for Statistical Computing, Vienna, Austria. ISBN 3-900051-07-0, URL http://www.R-project.org.

[28] Kessler, M. 2002. The elevational gradient of Andean plant endemism: varying influences of taxon- specific traits and topography at different taxonomic levels. Journal of Biogeography. 29: 1159-1165.

[29] Werff, H. V. A. N. D. E. R. \& Consiglio, T. 2004. Distribution and conservation significance of endemic species of flowering plants in Peru, Biodiversity and Conservation, 13: 1699-1713.

[30] Austin, M. P. 1980. Searching for a model for use in vegetation analysis. Vegetatio. 42: 11-21. doi: 10.1007/BF00048865

[31] Berhanu, A., Woldu, Z. \& Demissew, S. 2016. Elevation patterns of woody taxa richness in the evergreen Afromontane vegetation of Ethiopia. Journal of Forestry Research, http://doi.org/10.1007/s11676-016-0350-y

[32] Nogué, S., Rull, V. \& Vegas-Vilarrúbia, T. 2013. Elevational gradients in the neotropical table mountains: patterns of endemism and implications for conservation. Diversity and Distributions. 19: 676-687. doi: 10.1111/ddi.12017

[33] Brown, J. H. \& Lomolino, M. V. 1998. Biogeography (2nd edn). Courier Companies, Sunderland.
[34] Chust, G., Chave, J., Condit, R., Aguilar, S., Lao, S. \& Pérez, R. 2006. Determinants and spatial modeling of tree betadiversity in a tropical forest landscape in Panama. Journal of Vegetation Science. 17: 83-92.

[35] Legendre, P., Mi, X., Ren, H., Ma, K., Yu, M., Sun, I. F. \& He, F. 2009. Partitioning beta diversity in a subtropical broadleaved forest of China. Ecology. 90: 663-674.

[36] De Cáceres, M., Legendre, P., Valencia, R. \& Cao, M. et al. 2012. The variation of tree beta diversity across a global network of forest plots. Global Ecology and Biogeography. 21: 1191-1202.

[37] Zhong-Hua, Z., Hu, G. \& Ni, J. 2013. Effects of topographical and edaphic factors on the distribution of plant communities in two subtropical karst forests, southwestern China. Journal of Mountain Science. 10: 95-104.

[38] Huo, H., Feng, Q. \& Su, Y. 2015. Shrub communities and environmental variables responsible for species distribution patterns in an alpine zone of the Qilian Mountains, northwest China. Journal of Mountain Science. 12: 166-176.

[39] Tscharntke, T., Tylianakis, J. M. \& Rand, T. A. et al. 2012. Landscape moderation of biodiversity patterns and processes eight hypotheses. Biological Reviews. 87, 661-685.

[40] Jost, L., Devries, P., Walla, T., Greeney, H., Chao, A. \& Ricotta, C. 2010. Partitioning diversity for conservation analyses. Diversity and Distributions. 16: 65-76.

[41] Aerts, R., Spranghers, S. \& Şekercioğlu, Çh. 2016. Conservation of ecosystem services does not secure the conservation of birds in a Peruvian shade coffee landscape. Bird Conservation International. 1-12. http://doi.org/10.1017/S0959270916000149. 